\title{
No research about "them" without "them": CJPH policy with regard to publication of health research on First Nations, Inuit, Métis and Indigenous Peoples
}

\section{Pas de recherche sur " eux » sans « eux » : politique de la RCSP à l'égard de la publication d'articles de recherche sur la santé des Premières Nations, des Inuits, des Métis et des peuples autochtones}

\author{
Louise Potvin ${ }^{1}$ \\ Published online: 7 December 2020 \\ (C) The Canadian Public Health Association 2020
}

The health of First Nations, Inuit and Métis people in Canada is still significantly more precarious than that of the general population (Tjepkema et al. 2019). There is an urgent need for more action and research to address this national shame. But not just any research! Over the past decades, First Nations, Inuit and Métis leaders have rightly advocated that all research that concerns these communities should involve them. This plea was heard by the Canadian federal funding agencies. The Tri-Council Policy Statement on the ethical conduct of research involving humans makes it clear: research involving Indigenous people must be designed, conducted and reported based on a collaborative relationship with the concerned communities (CIHR, NSERC, SSHRC 2018).

With this journal issue, CJPH proudly launches its policy with regard to publication of health research on Indigenous Peoples (Smylie et al. 2020). The policy explicitly requires that articles submitted to CJPH reporting on a study about First Nations, Inuit, Métis and Indigenous Peoples from Canada and other countries explain how the researchers engaged with concerned communities and how the interpretation and contextualization of the results take into account the experiential knowledge of those whom the research is about. This policy applies to all research, regardless of whether it is using primary or secondary data.

Louise Potvin

louise.potvin@umontreal.ca

1 School of Public Health, Université de Montréal, Montreal, QC, Canada
This policy is the result of a process initiated some five years ago following the publication of a letter to the editor (King 2015). In his letter, Malcolm King, then Scientific Director of the CIHR Institute of Aboriginal People's Health, pleaded that instead of accepting that authors of articles presenting results from secondary analyses mention that further research is required to contextualize their findings, journals should challenge these authors to go the extra steps and include a meaningful contextualization in their original publication. The argument was compelling. As an Editorial Board, we embarked on the long and difficult process of developing a policy with regard to publication of research about First Nations, Inuit, Métis and Indigenous Peoples.

This policy is a guide for the authors and CJPH editors to operationalize the recommendations of the Tri-Council concerning research with Indigenous people (CIHR, NSERC, SSHRC 2018) at the stage of research publication. Its details are presented in a separate Invited Commentary (Smylie et al. 2020). In a nutshell, it defines what CJPH considers research involving First Nations, Inuit, Métis and Indigenous Peoples and requires explicit reporting on the ways in which concerned communities engaged with the research and their role. The policy was developed under the leadership of Dr. Janet Smylie by a group of CJPH's senior editors and representatives from the First Nations, Inuit and Métis communities. Dr. Smylie is a celebrated Métis physician, a Canada Research Chair in Advancing Generative Health Services for Indigenous Populations in Canada and a member of our Editorial Board. In a separate editorial, she and her group argue for the necessity and legitimacy of such a 
policy and reflect on the process they went through (Marsden et al. 2020).

Adopting this policy, CJPH's Editorial Board is aware that it might raise controversies and that some researchers may feel that we are crossing some line. We offer the following answers to some of the questions we anticipate.

Is CJPH being more restrictive than the Tri-Council in ensuring appropriate ethical research procedures, especially when it concerns secondary analyses? We do not perceive our policy as being more restrictive than the Tri-Council guidelines. Concerning secondary data analyses, it essentially operationalizes the recommendations formulated in Article 9.21 of the 2018 revision of the Tri-Council Policy Statement: Ethical Conduct for Research Involving Humans - TCPS 2 (CIHR, NSERC, SSHRC 2018). Secondary analyses are carried out on data collected on volunteer participants. For groups of Indigenous people, the requirement is that representatives from their community have been involved in the design and interpretation of primary analyses. We do not conceive of results of secondary analyses as being ethically and epistemologically different from those of primary analyses. Both concern real people who can be stigmatized by what is published about them. It is fair to ensure that those whose health is being discussed have the opportunity to provide contextual information relevant to such results at the time of publication.

Is CJPH censoring the publication of research? This is not at all our intention. CJPH is committed to publishing studies conducted respecting the highest ethical and methodological standards in our field. Our policy means that to be meaningful, results from primary and secondary analyses about Indigenous people's health need to be contextualized by those they concern and affect. In order for this to happen, there must be some form of dialogue between the research team and representatives from the Indigenous population. We want to ensure this happens and that the articles published in CJPH report on this process and on how the results of such dialogues were taken into account. This policy is not about preventing the publication of results that are not shedding a positive light on Indigenous people's health. Our aim is to invite the research community to engage first with Indigenous people when study results provide new knowledge that ultimately serves the purpose of improving the health and well-being of the Indigenous population concerned.

Why just this population? What about all other groups who suffer systematic discrimination? As a journal, we develop policies that are aligned with authoritative and legitimate statements about the responsible conduct of research. Our editorial policies are intended to further the operationalizing of such guidelines at the research publication stage. This is the second publication policy developed and adopted by CJPH recently. The first was launched in 2016. It was about reporting on sex and gender and was developed in reference to the CIHR guidelines for sex, gender and health research (Gahagan 2016). It is widely recognized that sex and gender is among the most important social determinants of health in Canada, second only perhaps to identifying as First Nations, Inuit or Métis. In addition, systematic racism towards this community has been acknowledged by the Canadian Government who engaged the Canadian population in a path of Reconciliation. At CJPH, we conceive of this policy as our contribution to this most needed national effort. Finally, we do not exclude the possibility of CJPH developing policies in the future with respect to other groups to the extent that relevant bodies provide explicit guidelines for the responsible conduct of research with those groups.

Indigenous scholars are already overloaded with work and representation, why is CJPH adding more to their plate with these requirements? This policy does not require that research about Indigenous people should be conducted by researchers identifying as First Nations, Inuit or Métis. It does state that all research reporting about Indigenous people's health should engage with Indigenous populations. This can be accomplished in numerous meaningful ways. There are many relevant groups with whom research results can and should be discussed and contextualized prior to publication of those results. We are not promoting any particular process, nor group. Conversely, that a researcher identifies as First Nations, Inuit or Métis does not spare him or her the responsibility of meaningfully engaging with the relevant communities and groups whose data are being analyzed and reported.

At the end of the day, this policy recognizes that research is a social enterprise that can no longer be considered as neutral. Unintended though it might have been, some research about them has effectively caused harm to the First Nation, Inuit and Métis Peoples in Canada and other Indigenous groups around the world. Because research is such a powerful instrument for change, CJPH takes the stance that research about Indigenous Peoples should ensure to engage with people from the concerned population before it engages with the rest of the world through our journal.

Louise Potvin, $\mathrm{PhD}$

Editor-in-Chief on behalf of the CJPH Editorial Board

\section{Éditorial}

La santé des Premières Nations, des Inuits et des Métis au Canada est encore considérablement plus précaire que celle de la population générale (Tjepkema et al. 2019). Il est urgent de renforcer l'action et la recherche pour laver cette honte nationale. Mais il ne s'agit pas de n'importe quelle recherche! Au cours des dernières décennies, des dirigeants inuits, métis et des Premières Nations ont fait valoir à raison que toute la recherche qui concerne leurs communautés devrait les impliquer. Leur appel a été entendu par les organismes de 
financement fédéraux du Canada. L'Énoncé de politique des trois Conseils sur l'éthique de la recherche avec des êtres humains est clair : la recherche impliquant les peuples autochtones doit être conçue, menée et communiquée sur la base d'une relation de collaboration avec les communautés concernées (CIHR, NSERC, SSHRC 2018).

Dans ce numéro, la RCSP lance avec fierté sa politique à l'égard de la publication d'articles de recherche sur la santé des peuples autochtones (Smylie et al. 2020). Il est explicitement demandé que les articles soumis à la RCSP qui font état d'une étude sur les Premières Nations, les Inuits, les Métis et les peuples autochtones du Canada et d'autres pays expliquent comment les chercheurs ont interagi avec les communautés en question, et en quoi l'interprétation et la contextualisation des résultats tient compte des connaissances empiriques des personnes qui font l'objet de la recherche. La politique s'applique à toute recherche, qu'elle utilise des données primaires ou secondaires.

Cette politique est l'aboutissement d'un processus amorcé il y a environ cinq ans, à la suite de la publication d'une lettre à la revue (King 2015). Dans sa lettre, Malcolm King, qui était alors Directeur scientifique de l'Institut de la santé des Autochtones des IRSC, faisait valoir qu'au lieu d'accepter que les auteurs d'articles présentant les résultats d'analyses secondaires mentionnent qu'il faut pousser la recherche pour mettre leurs constatations en contexte, les revues devraient lancer aux auteurs le défi d'en faire plus et d'inclure une véritable mise en contexte dans leur article original. L'argument était convaincant. Notre comité éditorial a donc entamé le long et difficile processus d'élaboration d'une politique à l'égard de la publication d'articles de recherche sur les Premières Nations, les Inuits, les Métis et les peuples autochtones.

La politique est un guide à l'intention des auteurs et des rédacteurs de la RCSP sur la mise en application des recommandations des trois Conseils concernant la recherche axée sur les peuples autochtones (CIHR, NSERC, SSHRC 2018) à l'étape de la publication de la recherche. La teneur de la politique est présentée dans un commentaire invité fourni séparément (Smylie et al. 2020). En gros, elle définit ce que la RCSP considère comme étant un article de recherche impliquant les Premières Nations, les Inuits, les Métis et les peuples autochtones et demande que soient explicitement communiquées les façons dont les communautés concernées ont participé à la recherche et quel a été leur rôle. La politique a été élaborée sous la direction de $\mathrm{D}^{\text {re }}$ Janet Smylie par un groupe de rédacteurs scientifiques adjoints de la RCSP et de représentants de communautés métisses, inuites et des Premières Nations. $\mathrm{D}^{\text {re }}$ Smylie est une femme médecin métisse de renom, titulaire de la Chaire de recherche du Canada en amélioration des services de santé pour les peuples autochtones du Canada et membre de notre comité éditorial. Dans un éditorial distinct, elle et son groupe plaident en faveur de la nécessité et de la légitimité d'une telle politique et retournent sur le processus par lequel ils sont passés (Marsden et al. 2020).

En adoptant cette politique, le comité éditorial de la RCSP est conscient qu'elle pourrait susciter la controverse, et que des chercheurs pourraient considérer que nous dépassons certaines bornes. Nous proposons les réponses suivantes aux questions que nous anticipons.

La RCSP est-elle plus stricte que les trois Conseils en faisant respecter des méthodes adaptées à une recherche éthique, surtout en ce qui concerne les analyses secondaires? Nous ne considérons pas notre politique comme étant plus restrictive que les lignes directrices des trois Conseils. En ce qui a trait aux analyses de données secondaires, elle applique essentiellement les recommandations formulées à l'article 9.21 de la version de 2018 de l'Énoncé de politique des trois Conseils : Éthique de la recherche avec des êtres humains EPTC 2 ( CIHR, NSERC, SSHRC 2018). Les analyses secondaires sont effectuées sur des données recueillies auprès de participants consentants. Pour les groupes de personnes autochtones, l'exigence est la suivante : que des représentants de leur communauté aient participé à la conception et à l'interprétation des analyses primaires. Nous ne considérons pas les résultats des analyses secondaires comme étant différents, sur le plan éthique et épistémologique, de ceux des analyses primaires. Dans les deux cas, il s'agit de personnes réelles qui peuvent être stigmatisées par ce qui est publié à leur sujet. Il est raisonnable que les personnes dont la santé est débattue aient la possibilité d'offrir des informations contextuelles sur ces résultats au moment où ils sont publiés.

La RCSP censure-t-elle la publication d'articles de recherche? Ce n'est pas du tout notre intention. La RCSP entend publier des études menées dans le respect des normes éthiques et méthodologiques les plus strictes de notre domaine. Notre politique signifie que pour être sérieux, les résultats d'analyses primaires et secondaires axées sur la santé des peuples autochtones doivent être mis en contexte par les personnes touchées et concernées. Pour que ce soit le cas, il doit y avoir une forme de dialogue entre l'équipe de recherche et les représentants de la population autochtone. Nous voulons garantir que cela se produise, et que les articles publiés dans la RCSP décrivent ce processus et la façon dont les résultats de ces dialogues ont été pris en compte. Il ne s'agit pas d'empêcher la publication de résultats qui jetteraient un éclairage négatif sur la santé des peuples autochtones. Notre objectif est d'inviter le monde de la recherche à commencer par communiquer avec les peuples autochtones quand les résultats d'une étude fournissent de nouvelles connaissances qui, à terme, serviront à améliorer la santé et le bien-être du peuple en question.

Pourquoi seulement cette population-là? Qu'en est-il des autres groupes victimes de discrimination systémique? Nous créons pour notre revue des politiques qui cadrent avec les 
énoncés officiels et légitimes sur la conduite responsable de la recherche. Nos politiques éditoriales visent à faire avancer la mise en application de telles directives à l'étape de la publication de la recherche. C'est la deuxième politique de publication créée et adoptée par la RCSP récemment. La première date de 2016. Elle concernait la communication d'informations sur le sexe et le genre et avait été créée en lien avec les lignes directrices des IRSC sur le sexe et le genre dans la recherche sur la santé (Gahagan 2016). Il est largement admis que le sexe et le genre sont les plus importants déterminants sociaux de la santé au Canada, après le fait de s'identifier comme étant Inuit, Métis ou membre des Premières Nations. De plus, le racisme systémique envers les peuples autochtones est reconnu par le gouvernement canadien, qui a engagé la population canadienne sur la voie de la réconciliation. À la RCSP, nous considérons cette politique comme notre contribution à cette démarche nationale des plus nécessaire. Enfin, nous n'excluons pas la possibilité que la RCSP élabore plus tard des politiques à l'égard d'autres groupes, dans la mesure où les organismes compétents publient des directives explicites pour la conduite responsable de la recherche avec ces groupes.

Les chercheurs autochtones sont déjà surchargés de travail et de demandes de représentation; pourquoi la RCSP alourdit-elle leur tâche avec ces exigences? Notre politique n'exige pas que la recherche sur les peuples autochtones soit menée par des chercheurs s'identifiant comme étant membres des Premières Nations, Inuits ou Métis. Elle stipule que tous les articles de recherche sur la santé des peuples autochtones doivent s'assurer de la participation des populations autochtones. Cela peut se faire de nombreuses façons concrètes. Il y a beaucoup de groupes pertinents avec lesquels les résultats de recherche peuvent et devraient être discutés et mis en contexte avant leur publication. Nous ne faisons la promotion d'aucun processus ou groupe particulier. Réciproquement, le fait qu'un chercheur s'identifie comme étant membre des Premières Nations, Inuit ou Métis ne l'exempte pas de l'obligation de collaborer véritablement avec les communautés et les groupes dont les données sont analysées et communiquées.
Au bout du compte, notre politique reconnaît que la recherche est une entreprise sociale qui ne peut plus être considérée comme étant neutre. Même si c'était involontairement, des études sur les Premières Nations, les Inuits et les Métis du Canada et sur d'autres groupes indigènes autour du monde ont réellement causé du tort à ces peuples. La recherche est un puissant vecteur de changement; la RCSP considère que la recherche sur les peuples autochtones doit s'assurer de communiquer avec les membres de la population concernée avant de communiquer avec le reste du monde par l'entremise de notre revue.

Louise Potvin, Ph.D.

Rédactrice en chef, pour le comité éditorial de la RCSP

\section{References/Références bibliographiques}

CIHR, NSERC, SSHRC (2018). Canadian Institutes of Health Research, Natural Sciences and Engineering Research Council of Canada, and Social Sciences and Humanities Research Council. Tri-Council Policy Statement: Ethical Conduct for Research Involving Humans. https://ethics.gc.ca/eng/documents/tcps2-2018-eninteractive-final.pdf. Accessed 30 September 2020.

Gahagan, J. (2016). Commentary on the new sex and gender editorial policy of the Canadian Journal of Public Health. Canadian Journal of Public Health, 107(2), e140-e141.

King, M. (2015). Contextualization of socio-culturally meaningful data. Canadian Journal of Public Health, 106(5), e457.

Marsden, N., Star, L., \& Smylie, J. (2020). Nothing about us without us in writing: aligning the editorial policies of the Canadian Journal of Public Health with the inherent rights of Indigenous Peoples (Invited Editorial). Canadian Journal of Public Health, 111(6). https://doi.org/10.17269/s41997-020-00452-w.

Smylie, J., Marsden, N., Star, L., Gahagan, J., Zarowsky, C., Mykhalovskiy, E., Masuda, J., \& Potvin, L. (2020). Requirement for meaningful engagement of First Nations, Inuit, Métis, and Indigenous Peoples in publications about them. Canadian Journal of Public Health. https://doi.org/10.17269/s41997-020-00450-y.

Tjepkema, M., Bushnik, T., \& Bougie, E. (2019). Life expectancy of First Nations, Métis and Inuit household populations in Canada. Health Reports, 30(12), 3-10. https://doi.org/10.25318/82-003x201901200001-eng.

Publisher's note Springer Nature remains neutral with regard to jurisdictional claims in published maps and institutional affiliations. 